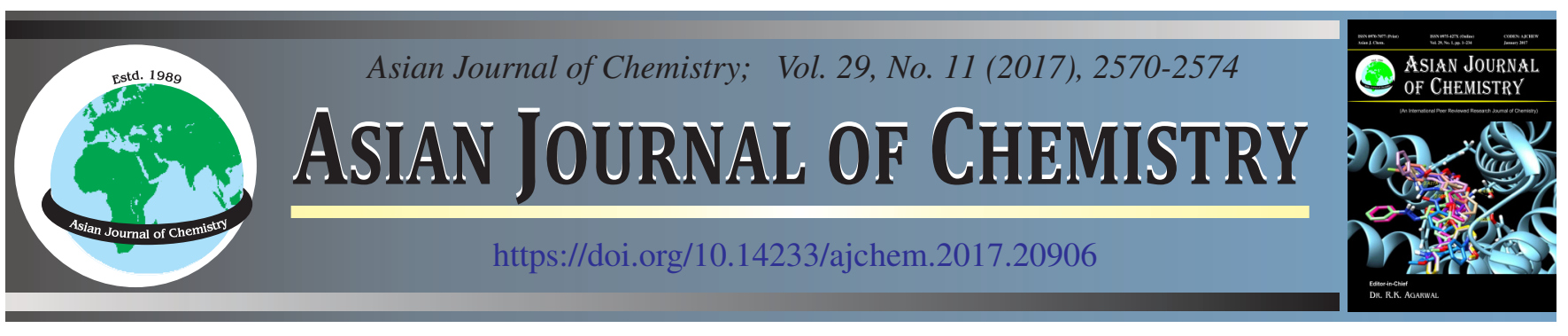

\title{
Comparison of Chemical Composition and Antioxidant Activity of Essential Oil of Gum-Resin Obtained from Juniperus excelsa and Boswellia sacra
}

\author{
Amani Al-Riyami, Nawal Al-Manthary, Saleh N. Al-Busafi ${ }^{*}$ and Salim H. Al-Saidi
}

Department of Chemistry, College of Science, Sultan Qaboos University, Box 36, Al-Khodh 123, Oman

*Corresponding author: Fax: +968 24141469; Tel: +968 24142305; E-mail: saleh1@ squ.edu.om showed lower antioxidant activity compared to ascorbic acid.

Keywords: Boswellia sacra, Juniperus excelsa, Essential oils, Monoterpenes, Antioxidant.

\section{INTRODUCTION}

Frankincense (Luban in Arabian) is an oleo-gum-resin obtained from the evergreen tree of Boswellia sacra (Family Burseraceae) that grows in the arid zone behind the Monsoon Mountains in Dhofar, south of Sultanate of Oman [1]. This oleo-gum-resin can also be produced by other Boswellia species such as B. serrata in India [2], B. frereana and B. carteri in Somalia [3], B. dalzielii in Nigeria [4] and B. socotrana in Yemen [5]. Frankincense has been used for centuries as fragrance material as well as traditional medicine to cure different kind of diseases. In Oman, crushed frankincense of B. sacra was used as a plaster to treat skin lesions and for healing bone fractures. The gum also made up into pills and taken to treat abdominal and chest pain [6]. In Yemen, the oleo-gum-resin of $B$. socotrana is used traditionally by the native inhabitants for relieving the pain in cavities and sweetening the breath [7]. The gum resin of $B$. dalzielii is used along with other medicines for the treatment of venereal diseases in Nigeria [8]. Frankincense extracted from the bark of $B$. serrata is still used in the traditional ayurvedic medicine in India [9].

Investigations of pharmacological activities of essential oil extracted from different type of frankincense reveal wideranging medicinal applications such as antibacterial, antifungal, anticancer, antiinflammatory and asthma medication [10-14]. In this regard, essential oil of $B$. sacra exhibits inhibition of the fungal growth and aflatoxins secretion for Aspergillus flavus and A. parasiticus by 83.7 and $83.5 \%$, respectively [15]. Alcoholic extract of frankincense from $B$. serrata was reported to possess antiinflammatory and anti-arthritic activities in animals, which were attributed to the presence of boswellic acid derivatives in frankincense [16].

The chemical composition of essential oils of frankincense from different species of Boswellia plant has been investigated in several studies. These studies displayed variable proportion of monoterpenes and sesquiterpenes from one region to another. The essential oil of oleo-gum-resin of $B$. serrate was dominated by $\beta$-eudesmene, $\gamma$-murolene, $\gamma$-cadinene and $\alpha$-copaene (3.3, $3.0,2.9$ and $2.8 \%$, respectively) [2]. On the other hand, high percentages of $\alpha$-pinene $(45.7 \%), \gamma$-terpinene $(11.5 \%)$ and trans-sabinene hydrate $(4.6 \%)$ were found in the essential oil of the gum of $B$. dalzielii [4]. The chemical composition of essential oil of $B$. carteri revealed the following terpenes: $\alpha$-thujene $(19.2 \%)$, sabinene $(9.4 \%)$, limonene $(7.8 \%), \alpha$-pinene $(7.2 \%)$, octyl acetate $(60.0 \%)$, octanol $(12.7 \%)$ and $p$-cymene $(8.7 \%)$ [17]. Previous study on the essential oils of $B$. sacra revealed the following monoterpenes: $\alpha$-pinene (76.0\%), limonene (2.6\%), $\beta$-selinene (1.5\%) [18]. Recently, an oxygenated sesquiterpene muskatone isolated from the essential oil of $B$. sacra was identified as a potent odorant in frankincense [19].

Juniper tree (Juniperus excelsa) grows in the high altitude of Jabal al Akhdar of Oman in an open dry mountain forest 
where the altitude reaches about 2,300 $\mathrm{m}$. In addition, $J$. excelsa can be found throughout the eastern Mediterranean from northeastern Greece and southern Bulgaria across Turkey to Syria and Yemen [20]. Traditionally, J. excelsa is used in folk medicine to treat different ailments such as abdominal rigidity, asthma, fever, headache, diabetes and leucorrhoea [21-23]. In other parts of the world, the plant is considered useful as an antihypertensive, diuretic, appetizer, carminative, stimulant, anticonvulsant, flavoring agent and as a remedy for tuberculosis [24,25].

Bioactivity studies that performed on J. excelsa exhibited antibacterial [26], antifungal [27] and bronchodilatory activities [28]. Sandracopimaric acid, a diterpene isolated from J. excelsa was found to exhibit significant antibacterial activity against Bacillus subtilis, Staphylococcus aureus and Streptococcus durans [24]. Moreover, hexane extract of the berries of J. excelsa exhibited potent activity against human colon cancer cell line [29].

Chemical compositions of essential oil of J. excelsa leaves and fruits revealed diverse ratios of monoterpenes and sesquiterpenes from one region to another. Analysis of essential oil of the leaves of J. excelsa from the Crimea revealed the presence of $\alpha$-pinene (56.2\%), limonene $(10.4 \%), \delta$-3-carene $(3.1 \%)$, camphene (2.9\%), $\beta$-pinene (1.2\%), $\alpha$-terpinene $(1.9 \%)$ and terpinolene $(0.8 \%)$ [30]. The essential oil extracted from the leaves of J. excelsa from Jammu (India) was reported to contain sabinene $(36.1 \%)$ and cedrol $(26.8 \%)$ as major components [31]. Chemical analysis of the leaves oil of $J$. excelsa from Greece revealed the presence of cedrol $(28.1 \%), \alpha$-pinene $(22.5 \%)$ and limonene (22.7\%) [32]. Fruits essential oil of J. excelsa from Iran showed $\alpha$-pinene $(89.5 \%)$, myrcene $(2.6 \%)$, germacrene $(2.2 \%)$ and limonene $(1.3 \%)$ with other minor components [33]. Essential oil of $J$. excelsa leaves from Oman has been found to possess limonene $(49.6 \%)$, germacrene $(9.6 \%), \delta$ 3 -carene $(5.9 \%), \alpha$-pinene $(4.81 \%)$ and $\gamma$-cadinene $(3.76 \%)$ [34].

In addition, juniper tree produces an oleo-gum-resin that appears on the surface of the stems. Physical examination of this resin reveals resemblance in term of colour, smell and shape with frankincense of Boswellia sacra. No reports were found in literature that describes the chemical contents of the essential oil extracted from oleo-gum-resin of J. excelsa. In this article, we are aiming to analyze the chemical compositions of essential oil of gum-resin of $J$. excelsa and compare it with that of frankincense using IR spectroscopy and GC-MS spectrometry. In addition, an antioxidant and radical scavenging activities of both oils are also provided.

\section{EXPERIMENTAL}

Oleogum resins of J. excelsa and B. sacra were collected from Jabal Al-Akhdhar (North of Oman) and Dhofar region (South of Oman), respectively. Herbarium sheets have been deposited at Sultan Qaboos University Herbarium collections (AlSaidi, Salim H, 01/Fa/15). The examined oleo-gum resins were collected from one plant of each species.

Extraction of volatile oil: The two essential oils were prepared by steam distilling freshly oleo-gum resin samples of J. excelsa $(70.0 \mathrm{~g})$ and B. sacra $(60.5 \mathrm{~g})$ using clevenger apparatus. Complete consumption of the two resin samples yielded $3.1 \mathrm{~g}$ (4.4\%) of J. excelsa gum oil and $1.4 \mathrm{~g}(2.3 \%)$ of B. sacra gum oil. Infrared spectra were performed on a Magna 560 spectrometer (Nicolet model).

Gas Chromatography analysis: Gas chromatography study was performed using Shimadzu GC-2014 instrument fitted with a flame ionization detector (FID) and Restek Rtx-1 cross-linked methyl silicon capillary column $(30 \mathrm{~m} \times 0.25$ mm I.D. $\times 0.25 \mathrm{~mm}$ film thickness). Temperature of the oven was increased from $31{ }^{\circ} \mathrm{C}$ to $271{ }^{\circ} \mathrm{C}$ at a rate of $3{ }^{\circ} \mathrm{C} / \mathrm{min}$. The temperatures of the injector and the interface were set at 275 ${ }^{\circ} \mathrm{C}$ and $300{ }^{\circ} \mathrm{C}$, respectively. Helium was used as a carrier gas with a linear velocity of $74.6 \mathrm{~cm} / \mathrm{s}$ and total flow rate of 39.9 $\mathrm{mL} / \mathrm{min}$. The split ratio was 1:23.

GC/MS analysis: Gas chromatograph-mass spectrometry (GC-MS) studies were accomplished using Shimadzu instrument (GC-MS-QP/5050A model) fitted with a quadrupole mass spectrometer and fused silica capillary column (J\&W Scientific DB-5MS model). The dimensions of the column are $0.25 \mathrm{~mm}$ I.D. $\times 30 \mathrm{~m} \times 0.25 \mathrm{~mm}$ film thickness. Oven's temperature was controlled to increase at a rate of $3{ }^{\circ} \mathrm{C} / \mathrm{min}$ from $31^{\circ} \mathrm{C}$ to 271 ${ }^{\circ} \mathrm{C}$. The temperatures of the interface and injector were kept at $300{ }^{\circ} \mathrm{C}$ and $275^{\circ} \mathrm{C}$, respectively. Helium was used as a carrier gas with a linear velocity of $44.6 \mathrm{~cm} / \mathrm{s}$. The column flow rate was $1.5 \mathrm{~mL} / \mathrm{min}$; total flow rate was $36 \mathrm{~mL} / \mathrm{min}$ and split ratio of $1: 21$. The ionization voltage and scan rate of the mass spectrometer were $70 \mathrm{eV}$ and $500 \mathrm{amu} / \mathrm{s}$, respectively and the mass spectra were documented continuously over mass range of 35$501 \mathrm{amu}$. The components of the two essential oils were identified by comparing their Linear Retention Indices (LRIs) with literature values. The Linear Retention Indices (LRIs) of the oils components were determined relative to the retention time (RT) of a homologous series of $n$-alkanes (C8-C30). The MS spectra were matched with the computer MS database (Wiley 229,000 library).

Antioxidant capacity: Antioxidant capacity of two essential oils was measured by applying the phosphomolybdenum protocol reported by Prieto et al. [35]. A $0.3 \mathrm{~mL}$ solution of each oil in methanol $(1 \mathrm{mM})$ was mixed with $3 \mathrm{~mL}$ solution of antioxidant reagent ( $28 \mathrm{mM}$ sodium phosphate, $0.6 \mathrm{M}$ sulfuric acid and $4 \mathrm{mM}$ ammonium molybdate) in a $4 \mathrm{~mL}$ capped vials. After incubation in a water bath at $95^{\circ} \mathrm{C}$ for $90 \mathrm{~min}$, the vials were cooled to room temperature and the absorptions were measured at $695 \mathrm{~nm}$ against a blank solution. The absorption measurements were repeated three times and the antioxidant capacities were recorded as ascorbic acid equivalent by applying the following linear equation:

$$
\left[\mathrm{A}=0.0013 \mathrm{C}+0.049 ; \mathrm{R}^{2}=0.974\right]
$$

where $\mathrm{A}$ is the absorbance at $695 \mathrm{~nm}$ and $\mathrm{C}$ is the concentration of ascorbic acid (mg/L).

Free radical scavenging capacity: Radical scavenging capacity of the two essential oils was measured by the reported DPPH (2,2-diphenyl-1-picrylhydrazyl) free radical method [36]. A mixture of $2.0 \mathrm{~mL}$ solution of DPPH in methanol (0.1 $\mathrm{mM})$ and $0.1 \mathrm{~mL}$ solution of oil sample in methanol $(0.1 \mathrm{mg} /$ $\mathrm{mL}$ ) was kept standing for $60 \mathrm{~min}$. The visible absorption of the mixture was measured at $517 \mathrm{~nm}$ with methanol as a blank. The results were recorded as an average of three trials and the radical scavenging capacity was determined by the percentage of DPPH consumed according to the following formula: 


$$
\text { Reduction }(\%)=\frac{(\mathrm{AB}-\mathrm{AA})}{\mathrm{AB}} \times 100
$$

where $\mathrm{AB}=$ absorption of blank sample and $\mathrm{AA}=$ absorption of tested oil solution.

\section{RESULTS AND DISCUSSION}

The essential oils of gum-resin of J. excelsa and B. sacra were obtained by conventional hydrodistillation of the crushed gums. The essential oil of gum-resin of J. excelsa $(4.4 \% \mathrm{w} / \mathrm{w})$ was colourless oil which solidified with time to white solid while that of B. sacra $(2.3 \% \mathrm{w} / \mathrm{w})$ was light yellow oil. Both oils have nice sweetly smell.

IR analysis: IR spectra of gum-resin of J. excelsa revealed the presence of $\mathrm{O}-\mathrm{H}$ stretch at $3438 \mathrm{~cm}^{-1}$, aliphatic $\mathrm{C}-\mathrm{H}$ stretch at $2965 \mathrm{~cm}^{-1}, \mathrm{C}=\mathrm{O}$ stretch at $1731 \mathrm{~cm}^{-1}, \mathrm{C}=\mathrm{C}$ stretch at $1684 \mathrm{~cm}^{-}$ ${ }^{1}$ and C-C stretch at 1447 and $1364 \mathrm{~cm}^{-1}$. IR analysis of gumresin of B. sacra showed the presence of O-H stretch at 3484 $\mathrm{cm}^{-1}$, aliphatic C-H stretch at $2919 \mathrm{~cm}^{-1}, \mathrm{C}=\mathrm{O}$ stretch at 1734 $\mathrm{cm}^{-1}, \mathrm{C}=\mathrm{C}$ stretch at $1685 \mathrm{~cm}^{-1}$ and $\mathrm{C}-\mathrm{C}$ stretch at 1447 and $1364 \mathrm{~cm}^{-1}$.

GC-MS analysis: The chemical composition and the relative contents of the two essential oils were determined by GC-FID and GC-MS analysis and are given in Table-1. Twentyfive components were identified from J. excelsa gum-resin oil representing $97 \%$ of the total oil (Table-1). The predominant compound in J. excelsa resin oil was $\alpha$-pinene (80.50\%), other compounds that could be identified in minute proportion were $E$-pinocarveol $(2.85 \%)$, limonene $(2.46 \%)$ and $E$-verbenol $(2.09 \%)$. Among the identified compounds, 12 compounds comprising $48 \%$ were monoterpene hydrocarbons and 13 compounds comprising $52 \%$ were oxygenated monoterpenes. The oil is characterized by the absence of sesquiterpenes.

The GC-FID and GC/MS analysis of the oil of B. sacra resin revealed the identification of 39 components representing $98 \%$ of the total oil (Table-1). The major compounds in $B$. sacra resin oil were $\alpha$-pinene $(38.47 \%$ ) followed by limonene $(13.36 \%)$. Other compounds like caryophyllene oxide $(3.03 \%)$, trans-pinocarveol $(3.98 \%)$, cis-piperitol (2.53 $\%), \beta$-selinene $(2.49 \%)$, myrcene $(2.38 \%), \alpha$-phellandren- 8 ol $(2.37 \%), \delta$-cadinene $(2.21 \%)$ exist in significant amounts. Among the identified compounds, 15 compounds comprising $38.5 \%$ were monoterpene hydrocarbons and ten compounds comprising $25.6 \%$ were oxygenated monoterpenes. The essential oil of gum-resin of $B$. sacra is distin-guished by the presence of fifteen sesquiterpenes (38.5\%).

In general, the two oils showed some similarities and differences in their monoterpene and sesquiterpenes chemical composition. Each oil contains twenty-five monoterpenes, in which the major component, $\alpha$-pinene, was detected in both oils with varied proportion $(80.50 \%$ in J. excelsa gum oil and $38.47 \%$ in $B$. sacragum oil). In addition, the two oils shared $18(56.25 \%)$ monoterpenes from a total of thirty-two different monoterpenes exist in both oils. Limonene present as a second major component (13.36\%) in B. sacra oil, but it was detected in very low amount in the $J$. excelsa oil $(2.46 \%)$. Moreover, the fifteen sesquiterpenes characterizing the $B$. sacra oil are absent in $J$. excelsa oil. In addition, the presence of high
TABLE-1

CHEMICAL COMPOSITION (\%) OF THE GUM-RESIN OIL OF B. sacra AND J. excelsa

\begin{tabular}{|c|c|c|c|c|}
\hline \multirow{2}{*}{ Compounds } & \multirow{2}{*}{$\begin{array}{l}\text { LRI } \\
(\exp )\end{array}$} & \multirow{2}{*}{$\begin{array}{c}\text { LRI } \\
\text { (lit.)* }\end{array}$} & \multicolumn{2}{|c|}{ Oil (\%) } \\
\hline & & & B. sacra & J. excelsa \\
\hline Tricyclene & 920.9 & 923.2 & 0.34 & 0.77 \\
\hline$\alpha$-Thujene & 924.8 & 927.8 & 1.32 & 0.19 \\
\hline$\alpha$-Pinene & 934.1 & 936.1 & 38.47 & 80.50 \\
\hline$\alpha$-Fenchene & 946.5 & 949.4 & - & 0.36 \\
\hline Camphene & 948.0 & 950.3 & 0.99 & 0.57 \\
\hline Thuja-2,4(10)diene & 951.5 & 955.6 & 0.74 & 0.96 \\
\hline Sabinene & 971.0 & 973.0 & 0.88 & 0.22 \\
\hline$\beta$-Pinene & 976.7 & 977.7 & 0.84 & 1.03 \\
\hline Myrcene & 990.2 & 989.2 & 2.38 & 0.14 \\
\hline$p$-Cymene & 1023.5 & 1024.3 & 3.16 & 2.46 \\
\hline Limonene & 1028.2 & 1029.5 & 13.36 & 0.10 \\
\hline 1,8-Cineole & 1032.5 & 1031.8 & 0.23 & 0.1 \\
\hline$\gamma$-Terpinene & 1056.1 & 1059.7 & 0.4 & - \\
\hline Linalool oxide & 1084.3 & 1083.3 & - & 0.25 \\
\hline p-Cymene & 1090.3 & 1087.9 & - & 0.33 \\
\hline Linalool & 1098.3 & 1098.0 & 0.22 & 0.13 \\
\hline cis-Sabinene hydrate & 1100.5 & 1101.0 & 0.26 & - \\
\hline$\alpha$-Campholenal & 1125.6 & 1127.0 & 0.61 & 1.31 \\
\hline E-Pinocarveol & 1139.3 & 1141.0 & 3.98 & 2.85 \\
\hline cis-Verbenol & 1142.0 & 1144.2 & 1.78 & - \\
\hline trans-Verbenol & 1144.5 & 1144.0 & - & 2.09 \\
\hline Isoborneol & 1158.0 & 1158.2 & - & 0.38 \\
\hline$\alpha$-Phellandren-8-ol & 1170.9 & 1170.0 & 2.37 & - \\
\hline Terpinene-4-ol & 1178.8 & 1179.0 & 1.79 & 0.11 \\
\hline$\alpha$-Terpineol & 1185.8 & 1185.0 & - & 0.55 \\
\hline Myrtenal & 1193.2 & 1192.0 & - & 0.47 \\
\hline cis-Piperitol & 1194.8 & 1194.7 & 2.53 & - \\
\hline Verbenone & 1205.5 & 1206.2 & 2.27 & 0.44 \\
\hline trans-Carveol & 1217.8 & 1217.1 & 1.38 & 0.26 \\
\hline Carvone & 1241.9 & 1242.0 & 0.8 & - \\
\hline$p$-Anisyl alcohol & 1282.0 & 1282.3 & 0.84 & 0.49 \\
\hline$\alpha$-Terpineol acetate & 1344.5 & 1347.0 & 0.89 & - \\
\hline Carvacrol acetate & 1371.5 & 1373 & 0.49 & - \\
\hline Geranyl acetate & 1378.9 & 1379.9 & 0.33 & - \\
\hline$\beta$-Cubebene & 1386.0 & 1386.6 & 1.67 & - \\
\hline$\beta$-Caryophyllene & 1414.1 & 1420.1 & 1.79 & - \\
\hline$\alpha$-Humulene & 1450.0 & 1453.1 & 0.88 & - \\
\hline$\beta$-Selinene & 1483.4 & 1485.0 & 2.49 & - \\
\hline cis- $\beta$-Guaiene & 1490.4 & 1489.0 & 0.79 & - \\
\hline$\alpha$-Selinene & 1493.8 & 1493.0 & 0.31 & - \\
\hline$\beta$-Bisabolene & 1507.9 & 1508.4 & 0.42 & - \\
\hline$\delta$-Cadinene & 1514.1 & 1513.1 & 2.21 & - \\
\hline Elemol & 1544.3 & 1547.5 & 0.43 & - \\
\hline Caryophyllene oxide & 1575.9 & 1580.6 & 3.03 & - \\
\hline$\delta$-Cadinol & 1637.3 & 1636.0 & 0.77 & - \\
\hline$\beta$-Eudesmol & 1649.2 & 1650.1 & 1.57 & - \\
\hline Total identified (\%) & & & $98 \%$ & $97 \%$ \\
\hline
\end{tabular}

LRI: Linear retention index [Ref. 37]

percentage of oxygenated monoterpenes in J. excelsa oil (52\%) compared to only $25.6 \%$ in B. sacra oil may explains its solidification to a white solid with time.

Total antioxidant activity: The antioxidant activity for the essential oils of J. excelsa and B. sacra was evaluated by using phosphomolybdenum method which is based on the reduction of $\mathrm{Mo}(\mathrm{VI})$ by the sample analyte and the subsequent formation of green phosphate $\mathrm{Mo}(\mathrm{V})$ complex with a maximum absorption at $695 \mathrm{~nm}$. Total antioxidant activity of the two 
essential oils, expressed as ascorbic acid (AA) equivalent (mg of AA per $g$ of oil), was obtained from the calibration curve of ascorbic acid as shown in Fig. 1. Essential oil of B. sacra showed higher total antioxidant activity than J. excelsa oil (646 mg ascorbic acid equivalents versus $282 \mathrm{mg}$, respectively) (Fig. 2).

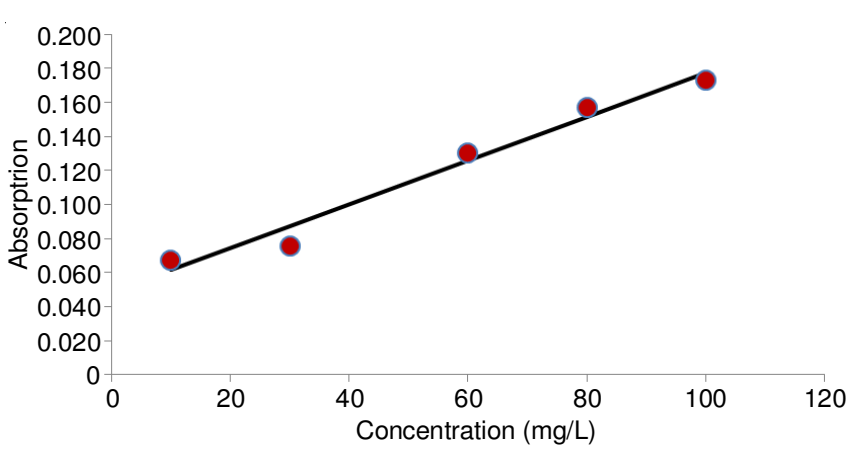

Fig. 1. Calibration curve of ascorbic acid (AA)

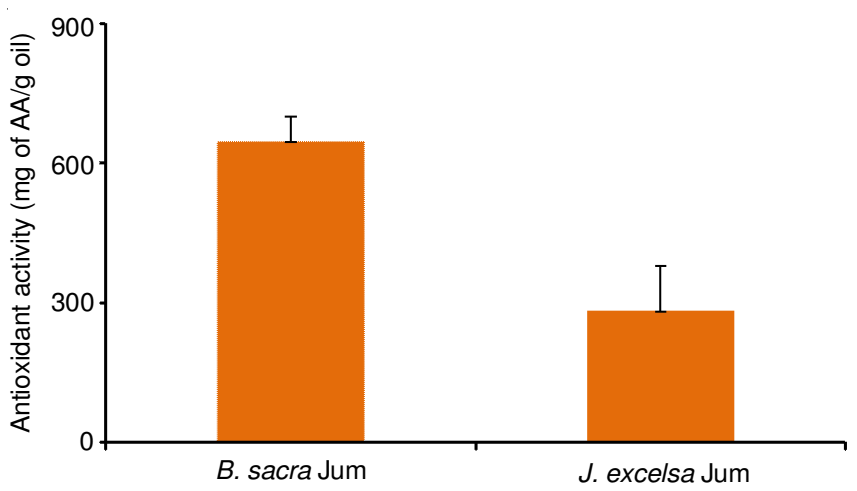

Fig. 2. Antioxidant activity of J. excelsa and B. sacra essential oils

DPPH radical scavenging activities: Another standard method to quantify antioxidant activity of essential oils is to measure their hydrogen donating ability to DPPH radical. In this study, essential oils of $J$. excelsa and B. sacra gum-resins were investigated for their radical scavenging activity and compared with that of ascorbic acid (Fig. 3). The scavenging activity of two essential oils as well as ascorbic acid increases as the concentration increases. Both oils, though, showed lower activity compared to that of ascorbic acid. Fig. 4 exhibited the $\mathrm{IC}_{50}$ values, which described the concentration of antioxidant required to inhibit $50 \%$ of DPPH radicals. The smaller $\mathrm{IC}_{50}$ values, the stronger antioxidant activity. The data obtained

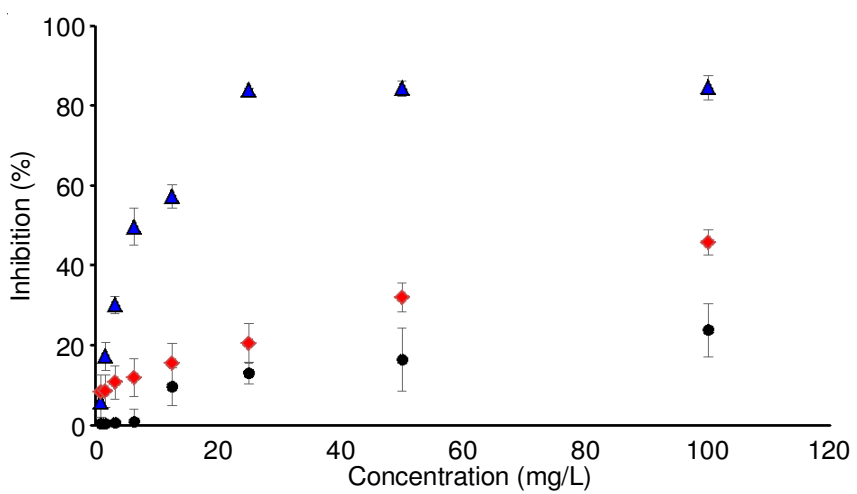

Fig. 3. DPPH radical inhibition activity of J. excelsa and B. sacra essential oils compared with ascorbic acid (AA) activity

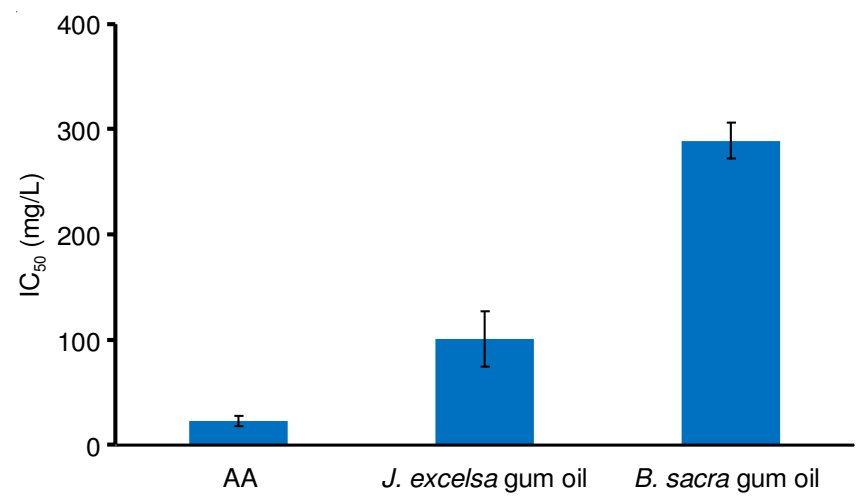

Fig. 4. $\mathrm{IC}_{50}$ values of ascorbic acid (AA), J. excelsa and B. sacra essential oils

indicated that the radical scavenging of the gum oil of J. excelsa $\left(\mathrm{IC}_{50}=100.4 \mathrm{mg} / \mathrm{L}\right)$ was stronger than that of $B$. sacra $\left(\mathrm{IC}_{50}=\right.$ $288.9 \mathrm{mg} / \mathrm{L})$.

\section{Conclusion}

Although Boswellia sacra gum (frankincense) and Juniper excelsa gum have similar texture and smell, their oil chemical composition which was revealed by GC-MS analysis showed some variations. J. excelsa gum contains $\alpha$-pinene as a major compound with $80.5 \%$ while $B$. sacra gum contains $\alpha$-pinene $(38.5 \%)$ and limonene $(13 \%)$ as major constituents. Both oils contain different proportion of other minor components. Sesquiterpenes exist in B. sacra gum oil only. Essential oil of $J$. excelsa gum showed weaker antioxidant activity than $B$. sacra gum oil, but both oils showed lower antioxidant activity compared to ascorbic acid.

\section{ACKNOWLEDGEMENTS}

The authors acknowledge the financial support from Sultan Qaboos University. The authors are grateful to Prof. Fakhr-Eldin Suliman for his valuable help. Thanks are also extended to Dr. Amina Al-Farsi for botanical identification of the plants.

\section{REFERENCES}

1. A.G. Miller and M. Morris, Plants of Dhofar: the Southern Region of Oman, Traditional, Economic and Medicinal Uses, Office of the Advisor for Conservation of the Environment, Diwan of Royal Court: Oman (1988).

2. A. Sharma, S. Chhikara, S.N. Ghodekar, S. Bhatia, M.D. Kharya, V. Gajbhiye, A.S. Mann, A.G. Namdeo and K.R. Mahadik, Phcog. Rev., 3, 206 (2009)

3. G. Chiavari, G.C. Galletti, R. Piccaglia and M.A. Mohamud, J. Essent. Oil Res., 3, 185 (1991); https://doi.org/10.1080/10412905.1991.9700500.

4. D. Kubmarawa, I.A. Ogunwande, D.A. Okorie, N.O. Olawore and A.A. Kasali, J. Essent. Oil Res., 18, 119 (2006); https://doi.org/10.1080/10412905.2006.9699038.

5. N.A. Ali, M. Wurster, N. Arnold, A. Teichert, J. Schmidt, U. Lindequist and L. Wessjohann, Rec. Nat. Prod., 2, 6 (2008); https://doi.org/10.3407/rpn.v2i1.17.

6. M.O. Fatope and S.N. Al-Busafi, Natural Products and their Active Compounds on Disease Prevention, In: Natural Products in the Prevention and Treatment of Invasive Human Diseases, Chap. 9, Nova Publishers (2012).

7. G.A. Miller and M. Morris, Ethnoflora of the Soqotra Archipelag, Charlesworth Group, Huddersfield, UK, pp. 457-464 (2004).

8. F.C. Nwinyi, L. Binda, G.A. Ajoku, S.O. Aniagu, N.M. Enwerem, A. Orisadipe, D. Kubmarawa and K.S. Gamaniel, Afr. J. Biotechnol., 3, 284 (2004); https://doi.org/10.5897/AJB2004.000-2052. 
9. C.F. Krieglstein, C. Anthoni, E.J.M. Rijcken, M. Laukötter, H.-U. Spiegel, S.E. Boden, S. Schweizer, H. Safayhi, N. Senninger and G. Schürmann, Int. J. Colorectal Dis., 16, 88 (2001); https://doi.org/10.1007/s003840100292.

10. S. Wahab, E. Aboutabl, S. El-Zalabani, H. Fouad, H. De Pooter and B. El-Fallaha, Planta Med., 53, 382 (1987); https://doi.org/10.1055/s-2006-962745.

11. M.L. Gangwal and D.K. Vardhan, Asian J. Chem., 7, 675 (1995).

12. T. Tsukada, K. Nakashima and S. Shirakawa, Biochem. Biophys. Res. Commun., 140, 832 (1986); https://doi.org/10.1016/0006-291X(86)90709-6.

13. M.L. Sharma, S. Bani and G.B. Singh, Int. J. Immunopharmacol., 11, 647 (1989); https://doi.org/10.1016/0192-0561(89)90150-1.

14. V. Gupta, S. Gupta, A. Gupta, R. Parihar, H. Ludtke and H.P.T. Ammon, Eur. J. Med. Res., 3, 511 (1998).

15. S.A.F. El-Nagerabi, A.E. Elshafie, S.S. Al-Khanjari, S.N. Al-Bahry and M.R. Elamin, Food Control, 34, 763 (2013); https://doi.org/10.1016/j.foodcont.2013.06.039.

16. G. Kesava Reddy, S.C. Dhar and G.B. Singh, Agents Actions, 22, 99 (1987); https://doi.org/10.1007/BF01968824.

17. W. Wang, Y.X. Zhu, L.Z. Liy, D.K. Link, X.L. Qin and J.G. Tian, Yaowu Fenxi Zazhi, 13, 170 (1993).

18. S. Al-Saidi, K.B. Rameshkumar, A. Hisham, N. Sivakumar and S. AlKindy, Chem. Biodivers., 9, 615 (2012); https://doi.org/10.1002/cbdv.201100189

19. J. Niebler, K. Zhuravlova, M. Minceva and A. Buettner, J. Nat. Prod. 79, 1160 (2016); https://doi.org/10.1021/acs.jnatprod.5b00836.

20. R.P.Adams, Juniper of the World: The Genus Juniperus, Tafford Publishing, USA (2008)

21. E. Schlecht, U. Dickhoefer, E. Gumpertsberger and A. Buerkert, J. Arid Environ., 73, 355 (2009); https://doi.org/10.1016/j.jaridenv.2008.10.013.

22. K.M. Nadkarni, Indian Materia Medica, Popular Prakashan, Bombay, edn 3, p. 713 (1976)

23. S.R. Baquar, Medicinal and Poisonous Plants of Pakistan, Printas, Karachi, p. 248 (1989).
24. I. Muhammad, J.S. Mossa and F.S. El-Feraly, Phytother. Res., 6, 261 (1992); https://doi.org/10.1002/ptr.2650060508

25. K. Usmanghani, A. Saeed and M.T. Alam, Indusyunic Medicine, University of Karachi Press, Karachi, p. 468 (1997).

26. I. Muhammad, J.S. Mossa, M.A. Al-Yahya, A.F. Ramadan and F.S. ElFeraly, Phytother. Res., 9, 584 (1995); https://doi.org/10.1002/ptr.2650090810.

27. M. Sokovic, M. Ristic and D. Grubisic, Pharm. Biol., 42, 328 (2004); https://doi.org/10.1080/13880200490511936.

28. M. Khan, A. Khan, Najeeb-ur-Rehman and A.-H. Gilani, J. Nat. Med., 66, 292 (2012); https://doi.org/10.1007/s11418-011-0605-z.

29. G. Topcu, R. Erenler, O. Cakmak, C.B. Johansson, C. Celik, H.-B. Chai and J.M. Pezzuto, Phytochemistry, 50, 1195 (1999); https://doi.org/10.1016/S0031-9422(98)00675-X.

30. Y.A. Akimov, S.I. Kuznestsov, G.I. Nilov, N.N. Chirkina, A.P. Krylova and R.M. Litvinenko, Nikitsk. Botan., Sad, 69, 79 (1976).

31. R.K. Thappa, S.G. Aggarwal, B.K. Kapahi and Y.K. Sarin, J. Nat. Prod., 50, 323 (1987); https://doi.org/10.1021/np50050a053.

32. R.P. Adams, J. Essent. Oil Res., 2, 45 (1990); https://doi.org/10.1080/10412905.1990.9697815.

33. E. Ehsani, K. Akbari, M. Teimouri and A. Khadem, Afr. J. Microbiol. Res., 6, 6704 (2012); https://doi.org/10.5897/AJMR12.686.

34. J. Hussain, N.U. Rehman, A. Al-Harrasi, L. Ali, A.L. Khan and M.A. Albroumi, Asian Pac. J. Trop. Dis., 3, 421 (2013); https://doi.org/10.1016/S2222-1808(13)60095-X.

35. P. Prieto, M. Pineda and M. Aguilar, Anal. Biochem., 269, 337 (1999); https://doi.org/10.1006/abio.1999.4019.

36. M.S. Blois, Nature, 181, 1199 (1958); https://doi.org/10.1038/1811199a0.

37. V.I. Babushok, P.J. Linstrom and I.G. Zenkevich, J. Phys. Chem. Ref. Data, 40, 043101 (2011); https://doi.org/10.1063/1.3653552. 